\title{
Edukasi dan Sosialisasi tentang Adversity Quotient dalam Upaya Pengembangan Kepemimpinan Diri Bagi Staff Kelurahan X, Kecamatan Y, Kota Bandung
}

\author{
Elty Sarvia*1, Wawan Yudiantyo*2, Kartika Suhada*3, Christina*4 \\ *Program Studi Teknik Industri, Fakultas Teknik, Universitas Kristen Maranatha \\ Prof. Drg. Suria Sumantri, No.65, 40164, Sukawarna, Kec. Sukajadi, Kota Bandung, Jawa Barat 40164 \\ 1elty.sarvia@eng.maranatha.edu, ${ }^{2}$ wawan.yudiantyo@eng.maranatha.edu, ${ }^{3}$ kartika.suhada@eng.maranatha.edu , \\ ${ }^{4}$ christina@eng.maranatha.edu
}

\begin{abstract}
Abstrak - Siapapun sebenarnya bisa jadi pemimpin. Tiap orang mempunyai talenta, keterampilan dan keahlian tertentu yang tidak dipunyai oleh orang lain. Seorang pemimpin dibutuhkan untuk mengatur organisasi menjadi lebih baik, efektif dan efisien. Mengembangkan potensi menjadi seorang pemimpin berarti mengubah sebagian untuk diri kita, seperti memperbaiki kelemahan kita, mengubah karakter diri menjadi lebih baik dan positip, cara pandang yang baik dan luas , dan memiliki kemampuan dan keahlian untuk memimpin. Tujuan dari kegiatan ini adalah memberikan pemahaman lebih jauh bagi staff di kelurahan $X$ bahwa pemimpin yang berhasil perlu mempunyai karakter kepemimpinan yang baik. Salah satunya adalah Adversity Quotient (AQ), yaitu kemampuan bertahan dalam menghadapi kesulitan dan mengatasinya. Metode yang digunakan adalah dengan pendekatan edukatif dengan memberikan pelatihan secara offline dan pemutaran video. Kegiatan edukasi dan sosialisasi ini di adakan dengan cara membagikan kuesioner terlebih dahulu di awal acara dan dilanjutkan dengan presentasi oleh tutor. Diakhir acara, hasil dari kuesioner AQ tadi akan diumumkan kepada peserta sehingga di harapkan dapat memberikan masukan kepada peserta apa saja kekurangan dan kelebihaan yang dimilikinya. Sebanyak $78 \%$ peserta masih berada di kategori moderately AQ (Adversity Quotient) dan hanya $22 \%$ berada di kategori moderately high $A Q$.
\end{abstract}

Kata kunci-Kepemimpiminan, Adversity Quotient, edukasi

Abstract - Anyone can be a leader. Everyone has certain talents, skills and expertise that others do not have. A leader is needed to manage the organization to be better, more effective and efficient. Developing the potential to be a leader means changing parts of ourselves, such as improving our weaknesses, changing our character to be better and positive, having a good and broad perspective, and having the ability and expertise to lead. The purpose of this activity is to provide further understanding for staff in Kelurahan $X$ that successful leaders need to have good leadership characteristics. One of them is Adversity Quotient (AQ), namely the ability to survive in the face of adversity and overcome it. The method used is an educational approach by providing offline training and video playback. This educational and socialization activity was held by distributing questionnaires at the beginning of the event and followed by a presentation by the tutor. At the end of the event, the results of the $A Q$ questionnaire will be announced to participants so that it is expected to provide input for the participants about their strengths and weaknesses. As many as $\mathbf{7 8 \%}$ of participants are still in the moderately AQ (Adversity Quotient) category and only $22 \%$ are in the moderately high $A Q$ category.

\section{Keywords—Leadership, Adversity Quotient, education}

\section{PENDAHULUAN}

Pemimpin adalah seseorang yang memiliki kemampuan untuk mempengaruhi orang lain atau kelompok untuk mewujudkan sebuah visi melalui misi yang telah ditetapkan. Pemimpin ialah orang yang melakukannya, orang yang memimpin. Sedangkan kepemimpinan ialah keterampilan, kecakapan, kemampuan dan tingkat pengaruh pada seseorang serta cara dalam memimpin. Siapapun sebenarnya bisa jadi pemimpin. Tiap orang mempunyai talenta, keterampilan dan keahlian tertentu yang tidak dipunyai oleh orang lain. Manakala orang itu menggunakannya untuk mempengaruhi orang lain berbuat apa yang dia mau, maka dia sudah menjadi pemimpin. Yang jadi penting disini ialah bagaimana kepemimpinannya. 
Artinya cara pandang, metode, karakter, kemampuan dan keahlian seseorang untuk memimpin.

Seorang pemimpin organisasi akan diakui sebagai seorang pemimpin apabila ia dapat mempunyai pengaruh dan mampu mengarahkan bawahannya untuk mencapai tujuan organisasi. Apabila pimpinan mampu mengorganisasikan dengan baik, sangat mungkin organisasi tersebut akan mencapai sasarannya [1]. Gaya kepemimpinan merupakan norma perilaku yang digunakan oleh seseorang pada saat orang tersebut mencoba mempengaruhi perilaku orang lain seperti yang dia lihat [2]. Dalam bekerja, bukan hanya terkait sikap dan perilaku dari orang yang bekerja, tapi juga dituntut perhatian dan keseriusan dalam melakukan tanggung jawab kerja untuk pencapaian hasil kerja yang optimal sesuai target yang diharapkan dalam suatu organisasi [3]. Jika masing-masing anggota tim dalam organisasi atau perusahaan memahami pentingnya sebuah kerjasama, maka hubungan kerja antar bagian/unit kerja akan berjalan dengan baik dan lancar, sehingga tujuan program-program yang sudah direncanakan mudah dicapai [4].

Kepemimpnan terkait dengan membangkitkan inspirasi, menciptakan berbagai peluang, membimbing dan memotivasi anggota tim agar setiap anggota dapat meraih keuntungan dari pilihan-pilihan jangka panjang [5]. Kepemimpinan dibutuhkan dalam organisasi karena orang menyadari bahwa menjadi pemimpin yang baik dapat mengubah kehidupan lebih baik. Tujuan dari leadership adalah melibatkan tim menyelesaikan suatu pekerjaan dengan cara yang tepat [6]. Salah satu yang menjadi karakter seorang pemimpin ialah menunjukan seberapa jauh pemimpin mampu bertahan menghadapi kesulitan yang dihadapinya dan kemampuan untuk mengatasi kesulitan tersebut. Hal ini dikenal dengan istilah Adversity Quotient atau disingkat $\mathrm{AQ}$, yang meliputi kemampuan seorang pemimpin untuk mengendalikan kesulitan, kemampuan mencari tahu sumber kesulitan tersebut dan kemampuan untuk memprediksi akibat bila tidak mampu mengatasi kesulitan tersebut, kemampuan untuk bertahan terhadap kesulitan tersebut serta bagaimana mengatasi kesulitan tersebut. Hal ini menjadi salah satu penentu keberhasilan seorang pemimpin. Saat ini, pengelolaan sumber daya manusia telah menjadi isu penting di segala bidang, mengingat pentingnya kontribusi mereka dalam setiap proses [7]. Sebuah tim bisa gagal, bila anggota tim tidak puas dengan sistem penghargaan atau dikarenakan banyaknya kendali atas tindakan mereka [8]. Kerja tim merupakah salah satu kegiatan yang tidak dapat dihindarin dalam organisasi mana pun [9].

Tujuan yang ingin dicapai dari kegiatan ini ialah :

- Memberikan pemahaman bahwa siapa saja bisa menjadi pemimpin.
- Memberikan pemahaman bahwa pemimpin yang berhasil perlu mempunyai karakter kepemimpinan yang baik agar berhasil.

- Memberikan pemahaman bahwa salah satu penentu keberhasilan dalam memimpin ialah Adversity Quotient, yaitu kemampuan bertahan dalam menghadapi kesulitan dan mengatasinya.

- Memberikan pemahaman bagaimana mengetahui kelemahan dirinya untuk bisa menjadi pemimpin yang berhasil mengatasi kesulitan. Sehingga bisa diperbaiki dikemudian hari, sehingga menjadi pemimpin yang baik dan berhasil.

\section{MASALAH}

Dalam kehidupan, kesulitan pasti ditemui oleh setiap orang. Suatu kesulitan bisa berdampak baik pada orang yang bisa mengatasinya, atau berdampak buruk bagi orang yang tidak dapat mengatasinya. Kesulitan bisa dipandang sebagai suatu tantangan untuk belajar dan mendalami sesuatu, sehingga semakin banyak kesulitan yang dihadapinya, semakin ahli dia dalam memimpin. Disisi lain, kesulitan juga bisa menjadi malapetaka bagi seseorang. Dimana kesulitan dipandang sebagai suatu halangan, rintangan, beban dan penganggu yang menghalangi kesuksesannya, yang mana membuat dia menjadi lemah dan akhirnya putus asa. Jadi, yang berbeda ialah bagaimana cara orang tersebut menghadapi kesulitan tersebut. Begitu juga bagi seorang pemimpin. Masalah yang terjadi di Kelurahan $\mathrm{X}$ Kecamatan $\mathrm{Y}$ adalah keinginan untuk meningkatkan motivasi dan kepemimpinan diri dari masing-masing anggota yang ada, agar organisasi tersebut dapat makin maju dan dapat menghasilkan yang terbaik bagi kelurahannya

\section{METODE PELAKSANAAN}

Pada kesempatan ini, kami diberi kesempatan untuk memperkenalkan Adversity Quotient kepada staff dan pimpinan kantor kelurahan X, kecamatan Y, Kota Bandung dengan metode edukasi dan sosialisasi. Jumlah peserta yang mengikuti program ini berjumlah 19 orang. Kegiatan ini diadakan pada 27 Juni 2019. Pada kesempatan ini, Pak Lurah juga ikut dalam pelatihan ini. Dikarenakan keterbatasan tempat di kelurahan saat itu, maka pelaksanaan kegiatan ini diadakan di lingkungan Universitas Kristen Maranatha, Bandung.

Pada awal sesi, peserta di bagikan kuesioner, yang berisikan 29 pertanyaan mengenai Adversity Response Profile berdasarkan buku [10]. Hal ini bertujuan untuk mengetahui kemampuan peserta dalam menghadapi tantangan dalam hidupnya. Setelah peserta mengisi jawaban pertanyaan pada lembar jawaban, kegiatan di lanjutkan dengan presentasi mengenai materi "Adversity Quotient" dan pemutaran video yang berkaitan dengan materi. Sementara itu para asisten, menghitung nilai skor nilai AQ 
para peserta. Di akhir acara, skor AQ tersebut di bagikan secara pribadi kepada peserta, agar diharapkan dapat menjadi masukan yang positif bagi peserta di kemudian hari.
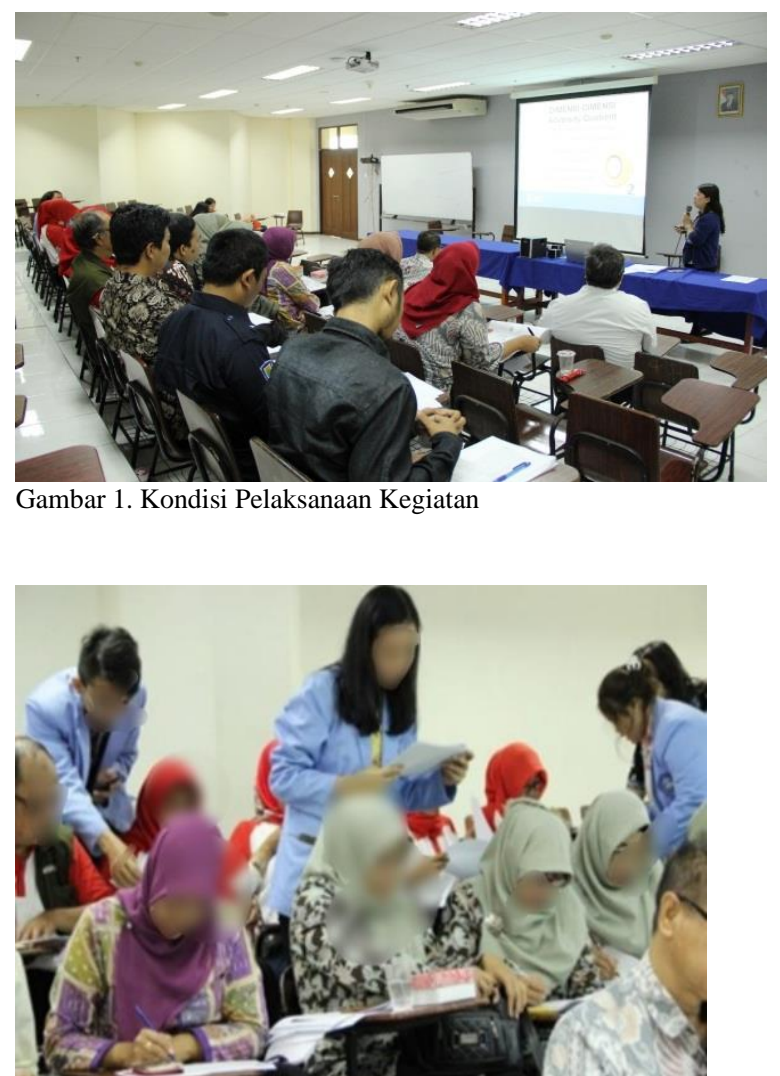

Gambar 2. Kondisi Peserta sedang mengisi Kuesioner Adversity Response Profile

\section{HASIL DAN PEMBAHASAN}

Adversity quotient merupakan kemampuan yang dimiliki seseorang dalam mengamati kesulitan dan mengolah kesulitan tersebut dengan kecerdasan yang dimiliki sehingga menjadi sebuah tantangan untuk diselesaikan. Adversity quotient sebagai suatu kemampuan terdiri dari empat dimensi yang disingkat dengan sebutan CO2RE yaitu dimensi control, origin- ownership, reach, dan endurance [10]. Dari hasil perhitungan adversity quotient terhadap peserta dari Tim Pembinaan Kesejahteraan Keluarga (PKK), Lembaga Pemberdayaan Masyarakat, Karang Taruna dan Karyawan Kantor Kelurahan X, Kecamatan Y, Bandung yang mengikuti pelatihan ini, didapatkan hasil sebagai berikut

\section{A. Control (Kendali)}

Kendali yaitu sejauh mana seseorang mampu mempengaruhi dan mengendalikan respon individu secara positif terhadap situasi apapun. Kendali yang sebenarnya dalam suatu situasi hampir tidak mungkin diukur, kendali yang dirasakan jauh lebih penting. Dimensi control ini merupakan salah satu yang paling penting karena berhubungan langsung dengan pemberdayaan serta mempengaruhi semua dimensi CO2RE lainnya [10].

Berdasarkan hasil evaluasi pada dimensi Control terhadap 19 responden, terdapat 3 kategori dalam penilaian dimensi kontrol ini:

\section{Nilai Control}

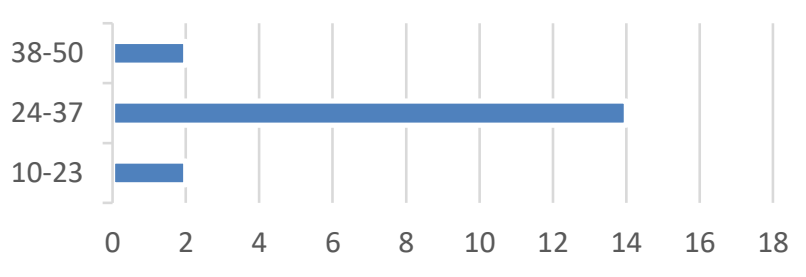

Gambar 3. Kategori Nilai Control Responden

Sebanyak 2 responden mendapat nilai diantara kisaran 38-50, yang artinya adalah bahwa responden sudah merasa mempunyai tingkat kendali yang kuat atas peristiwa-peristiwa yang buruk yang terjadi terhadap dirinya, serta responden memiliki pendekatan lebih berdaya dan proaktif. Untuk kategori ke 2, terdapat 14 responden yang mendapat nilai diantara kisaran 24-37, yang artinya responden dalam kategori tersebut merespon peristiwa buruk sebagai sesuatu berada dalam kendali (tergantung besarnya peristiwa). Responden tersebut mudah berkecil hati, sulit mempertahankan perasaan mampu memegang kendali bila dihadapkan pada kemunduran atau tantangan berat. Sedangkan sisanya terdapat 2 responden yang termasuk dalam kategori 10-23 responden yang membutuhkan pengembangan diri lebih, yaitu responden merasa peristiwa buruk yang terjadi di luar kendali, hanya sedikit yang bisa dilakukan untuk mencegah atau membatasi kerugian, sehingga hanya menyerah pada nasib.

Menurut [11] dalam [12] pengertian kontrol diri merupakan kemampuan individu untuk menentukan perilakunya atas standar seperti moral, nilai dan aturan di masyarakat agar terarah pada perilaku positif. Interaksi dengan orang lain dan lingkungan sekitarnya akan membentuk pola kontrol kiri yang matang terhadap kemampuan kontrol diri seseorang. Sehingga untuk nilai kontrol diri yang berbedabeda dalam hal ini, mungkin saja di pengaruhi oleh pengalaman interaksi perilaku responden dengan orang lain dan lingkungan sekitarnya yang berbeda-beda juga, yang memunculkan respon dan dampak tidak sama unruk masing-masing responden.

\section{B. Origin and Ownership}

yaitu sejauh mana seseorang menanggung akibat dari suatu 
situasi tanpa mempermasalahkan penyebabnya. Dimensi asal-usul sangat berkaitan dengan perasaan bersalah yang dapat membantu seseorang belajar menjadi lebih baik serta penyesalan sebagai motivator. Rasa bersalah dengan kadar yang tepat dapat menciptakan pembelajaran yang kritis dan dibutuhkan untuk perbaikan terus-menerus. Sedangkan dimensi pengakuan lebih menitik beratkan kepada "tanggung jawab" yang harus dipikul sebagai akibat dari kesulitan. Tanggung jawab di sini merupakan suatu pengakuan akibat-akibat dari suatu perbuatan, apapun penyebabnya. Seseorang yang memiliki kualitas origin yang cukup baik cenderung menempatkan rasa bersalah yang tidak berlebihan/ secukupnya, sebaliknya rasa bersalah yang berlebihan akan memberikan dampak buruk yang dapat menghancurkan semangat seseorang dikarenakan terbentuk pola pikir yang negatif. [10].

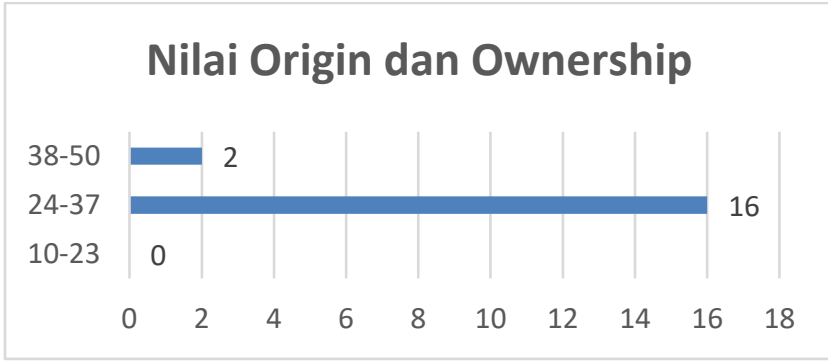

Gambar 4. Kategori Nilai Origin Responden

Dari hasil evaluasi yang diperoleh terlihat bahwa tidak terdapat responden yang berada di kategori 10-23, yang berarti tidak terdapat responden yang menganggap kesulitan yang dihadapinya sebagai sesuatu yang merupakan kesalahan mereka dan menganggap peristiwa yang baik sebagai keberuntungan. Rata-rata hasil pengujian terhadap responden mengenai dimensi ini berada pada kategori 24-37, yaitu sebanyak 16 orang. Jadi rata2 responden yang mengikuti pelatihan ini, merespon peristiwa dengan realitistis yaitu sebagai sesuatu yang kadang berasal dari luar dan kadang berasal dari diri sendiri. Sisanya terdapat 2 responden yang berada dalam kategori 38-50, yaitu mereka yang memiliki kemampuan untuk menghindari perilaku menyalahkan diri sendiri, yaitu memandang kesuksesan dan kesulitan terutama berasal dari pihak luar serta mencerminkan kemampuan untuk menghindari perilaku menyalahkan diri sendiri yang tidak perlu.

\section{Reach (Jangkauan)}

yaitu sejauh mana seseorang membiarkan kesulitan menjangkau bidang lain dalam pekerjaan dan kehidupannya. Seseorang dengan AQ tinggi memiliki batasan jangkauan masalahnya pada peristiwa yang dihadapi. Biasanya orang tipe ini merespon kesulitan sebagai sesuatu yang spesifik dan terbatas [10].

Dari hasil evaluasi yang diperoleh terlihat bahwa tidak terdapat responden yang berada di kategori 10-23, yang berarti tidak terdapat responden yang memandang kesulitan sebagai sesuatu yang merasuki wilayah-wilayah lain kehidupan anda. Rata-rata hasil pengujian terhadap responden mengenai dimensi ini berada pada kategori 2437 , yaitu sebanyak 15 orang. Jadi rata-rata responden yang mengikuti pelatihan ini, merespon peristiwa yang mengandung kesulitan sebagai sesuatu yang spesifik, namun kadang mungkin membiarkan peristiwa itu tidak perlu masuk wilayah lain dalam kehidupan. Sisanya terdapat 3 responden yang berada dalam kategori 38-50, yaitu mereka merespon kesulitan sebagai sesuatu yang spesifik dan terbatas. Jadi semakin efektif menahan atau pun membatasi jangkauan kesulitan, akan merasa lebih berdaya.

\section{Nilai Reach}

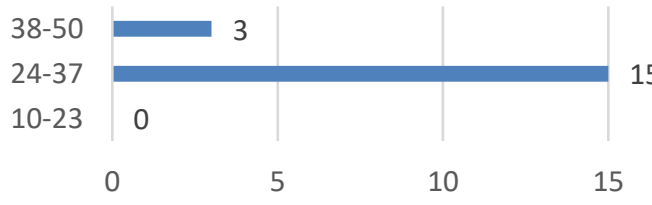

20

Gambar 5. Kategori Nilai Reach Responden

Work-life balance berkaitan dengan prioritas yang tepat antara pekerjaan (karier dan ambisi) dan gaya hidup (kesehatan, kesenangan, waktu luang, keluarga dan perkembangan spiritual). Konsep keseimbangan kehidupan kerja didasarkan pada gagasan bahwa pekerjaan yang dibayar dan kehidupan pribadi harus dilihat lebih sedikit sebagai prioritas yang berlawanan dan lebih sebagai esensi yang sesuai dari kehidupan yang penuh [13]. Seorang dalam bekerja dituntut oleh organisasinya untuk mencapai tujuan bersama, oleh karena itu harus mampu untuk mengatur waktunya bagi setiap kegiatan yang dibebankan pada setiap karyawan.

\section{Endurance (Daya Tahan)}

yaitu seberapa lama seseorang mempersepsikan kesulitan ini akan berlangsung. Individu dengan AQ tinggi biasanya memandang kesuksesan sebagai sesuatu yang berlangsung lama, sedangkan kesulitan-kesulitan dan penyebabnya sebagai sesuatu yang bersifat sementara. Daya tahan disini meliputi daya tahan fisik (kondisi tubuh yang sehat) dan psikis (mental yang sehat). Karyawan yang mempunyai daya tahan yang rendah akan selalu beranggapan bahwa permasalahan dan penyebabnya akan selalu ada dan membuat karyawan tersebut menjadi malas untuk mencoba, takut untuk berusaha, dan merasa kalah atau merasa tidak 
mampu dalam mengatasi tiap permasalahannya sebelum mencoba terlebih dahulu [10].

Kepemimpinan diciptakan bukan dilahirkan [14]. Ketahanan diri menghadapi tekanan di tempat kerja merupakan syarat wajib yang harus dimiliki seorang pimpinan dan pekerja saat ini. Seorang pekerja harus memiliki endurance yang baik agar bisa menjaga eksistensi dirinya di antara pesaing yang lain. Untuk itu seorang pekerja harus bisa fokus pada peningkatan (upgrade) kemampuan diri dan perbaikan diri sendiri (selfimprovement).

\section{Nilai Endurance}

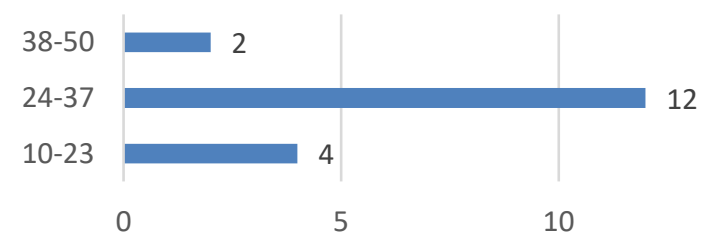

15

Gambar 6. Kategori Nilai Endurance Responden

Dari hasil evaluasi yang diperoleh terlihat bahwa terdapat 4 responden yang berada di kategori 10-23, yang berarti mereka yang memiliki perasaan tak berdaya sehingga memandang kesulitan dan penyebabnya sebagai peristiwa yang berlangsung lama dan peristiwa yang positif bersifat. Rata-rata hasil pengujian terhadap responden mengenai dimensi ini berada pada kategori 24-37, yaitu sebanyak 12 orang. Jadi rata-rata responden yang mengikuti pelatihan ini, merespon peristiwa -peristiwa yang buruk dan penyebabnya sebagai sesuatu yang berlangsung lama. Sisanya terdapat 4 responden yang berada dalam kategori 38-50, yaitu mereka yang memandang kesuksesan sebagai sesuatu yang berlangsung lama, menganggap kesulitan dan penyebabnya sebagai sesuatu yang sementara dan cepat berlalu.

\section{E. Adversity Quotient}

Pengelompokkan individu berdasarkan daya juangnya menjadi tiga [10]: quitter, camper, dan climber. Orang yang menyerah disebut quitter, orang yang merasa puas pada pencapaian tertentu sebagai camper, dan seseorang yang terus ingin meraih kesuksesan disebut sebagai climber [10].

Nilai Adversity Quotient dari responden yang mengikuti pelatihan memiliki rentang di dalam 2 kategori yaitu 95-134 dan 135-165. Kategori skor 95-134 adalah jumlah terbanyak yang terpilih oleh responden yang artinya nilai lumayan baik (Moderately AQ). Maksudnya Lumayan baik adalah rata-rata responden menempuh liku-liku hidup sepanjang segala sesuatunya berjalan relatif lancar, mungkin mengalami penderitaan yang tidak perlu, atau mungkin menjadi kecil hati dengan menumpuknya beban frustasi dan tantangan-tantangan hidup.

\section{Nilai Adversity Quotient}

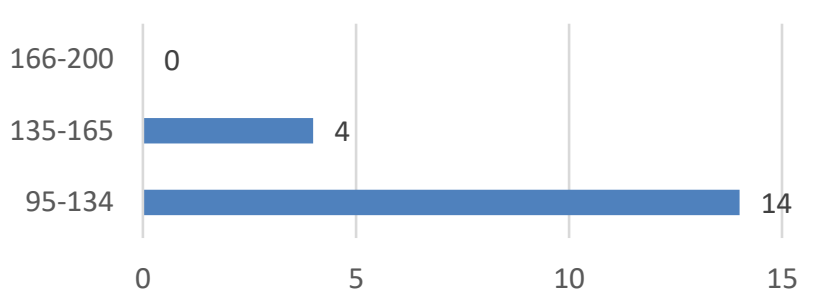

Gambar 7. Kategori Nilai Adversity Quotient Responden

Hanya terdapat 2 responden yang berada di kategori Moderately High AQ yaitu orang yang sudah cukup bertahan dalam menghadapi tantangan dan dapat memanfaatkan potensinya untuk berkembang. Dikarenakan nilai skor AQ banyak berada dikategori Moderately AQ, ada baiknya para peserta training melatih diri untuk meningkatkan Adversity Quotient (AQ) seperti dengan cara membuat reward atau punishment untuk dirinya sendiri demi menunjukkan kemampuan bertahan dalam menghadapi kesulitan sehingga dapat melampaui kinerja dan potensi mereka.

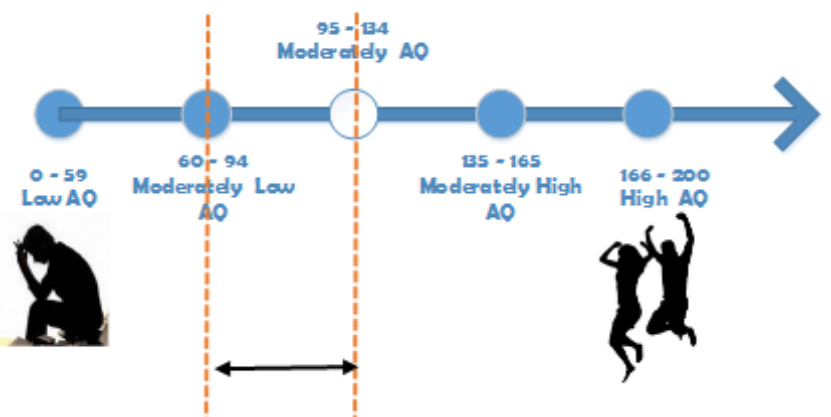

Gambar 8. Kategori Nilai Akhir Responden

\section{KESIMPULAN DAN SARAN}

Sebanyak $78 \%$ peserta masih berada di kategori moderately AQ (Adversity Quotient) dan hanya $22 \%$ berada di kategori moderately high AQ. Nilai AQ yang masih berada di range kategori rata-rata, disebabkan oleh peserta masih memiliki nilai control yang rata-rata seperti masih dapat mengendalikan peristiwa yang terjadi apabila dihadapkan pada tantangan berat, akan tetapi masih suka berkecil hati; nilai origin dan ownership yang berada di ratarata yaitu masih dapat merespon kesulitan yang kadang berasal dari dalam dan luar diri.; nilai reach yang rata-rata yaitu merespon kesulitan dengan spesifik, namun terkadang membiarkan peristiwa tersebut masuk ke dalam wilayah lain dalam kehidupannya.; nilai endurance yang rata-rata yaitu merespon kesulitan-kesulitan dan penyebabnya 
sebagai sesuatu yang berlangsung lama. Pelatihan ini merupakan langkah awal dari rangkaian pengabdian yang direncanakan, selanjutnya akan di lakukan pelatihan mengenai kerjasama tim yang dimana setelah masingmasing peserta sudah mengenali diri sendiri sehingga diharapkan mereka sudah mampu menilai dirinya ke depan dalam kerjasama tim nantinya. Setiap individual dalam tim pastinya ada perbedaan dan akan menghormati satu sama lain. Dengan adanya pemahaman diri sendiri dan menghargai perbedaan setiap anggota, diharapkan kerjasama tim dalam organisasi dalam berjalan baik dan lancar. Kunci keberhasilan suatu tim haruslah memastikan komunikasi, kolaborasi, koordinasi dan Kerjasama antar semua anggota. Setiap anggota harus bekerja untuk mencapai tujuan dan menyelaraskan tujuan tim. [15]. Untuk itu maka harus dimulai pengelolaan Adversity Quotient yang baik dari masing-masing individual.

\section{UCAPAN TERIMA KASIH}

Ucapan terima kasih diberikan kepada Kelurahan X, Kecamatan Y, Bandung, khususnya kepada Tim Pembinaan Kesejahteraan Keluarga (PKK), Lembaga Pemberdayaan Masyarakat (LPM), Karang Taruna dan karyawan Kantor Kelurahan Sukawarna. Terima kasih juga diberikan kepada Ketua Program Studi Teknik Industri (Ibu Christina S.T., M.T.) Universitas Kristen Maranatha, Bandung yang telah memfasilitasi kegiatan acara ini.

\section{DAFTAR PUSTAKA}

[1] Fimce Masambe, Agus S. Soegoto, Jacky Sumarauw, "Pengaruh Gaya Kepemimpinan, Budaya Organisasi Dan Inovasi Pemimpin Terhadap Kinerja Karyawan Daihatsu Kharisma Manado," Jurnal $E M B A$, vol. Vol.3 No.3, no. ISSN 2303-11, pp. Hal.939-949, 2015.

[2] Thofa, Miftah, Kepemimpinan dalam Manajemen, Jakarta: PT Raja Grafindo Persada, 2013.

[3] Pandelaki, Margotje Treisje, "Pengaruh Teamwork Dan Budaya Kerja Terhadap Kinerja Karyawan Yayasan Titian Budi Luhur Di
Kabupaten Parigi Moutong,” Katalogis, p. Volume 6 Nomor 5 Mei 2018, 2018.

[4] Setiyanti, Sri Wiranti, "Membangun Kerja Sama Tim (Kelompok)," Jurnal STIE Semarang, pp. Vol 4, No 3, Edisi Oktober 2012, 2012.

[5] Ray French, Charlotte Rayner, Gary Rees, Sally Rumbles, Organizational Behaviour, Third Edition, Chichester, West Sussex : John Wiley \& Sons, Inc, 2015.

[6] Plecas, Darryl, Colette Squires \& Len Garis, The Essentials of Leadership in Government, 2nd edition,: University of the Fraser Valley, 2018.

[7] Brock, S.E., et al, "Toward more practical measurement of teamwork skills.," Journal of Workplace Learning, vol. 29(2), pp. 124-133, 2017.

[8] Hu, J. and R.C. Liden, “ Making a difference in the teamwork: Linking team prosocial motivation to team processes and effectiveness.," Academy of Management Journal, vol. 58(4), pp. p. 1102-1127., 2015.

[9] Lemons, L. and J. Strong,, "Developing Teamwork and Team Leadership Skills through Service Learning. The Agricultural Education Magazine,," 2016. 89(1): p. 18

[10] P. G. Stoltz, Adversity Quotient: Mengubah Hambatan Menjadi Peluang, Jakarta: Grasindo, 2012.

[11] J. B. R. \&. B. Tangney, "High self control predicted good adjustment, less pathology, better grade, and interpersonal success," Journal of Personality, pp. 72(2) 271-324, 2004

[12] Ramadona Dwi Marsela, Mamat Supriatna,. "Kontrol Diri : Definisi dan Faktor," Journal of Innovative Counseling : Theory, Practice \& Research, pp. 3(2), pp. 65-69. ISSN (Print): 2548-3226, 2019.

[13] Fapohunda, Tinuke, "An Exploration of the Effects Of Work Life Balance On Productivity," Journal of Human Resources Management and Labor Studies, 2014.

[14] M. K. Sharma, "Leadership Management: Principles, Models and Theories," Global Journal of Management and Business Studies, p. vol 3 no. 3, 2013

[15] Abdulmajeed Alghamdi \& Christian Bach, "Developing Teamwork at Workplace," International Journal of Business and Management Invention (IJBMI), vol. Volume 7 Issue 2 Ver. III, no. ISSN (Online): 2319 - 8028, ISSN (Print): 2319 - 801X, pp. 2830, 2018 . 